\title{
Persepsi Orangtua Siswa Sekolah Dasar di Kota Gunungsitoli Terhadap Kebijakan Pembelajaran Jarak Jauh pada Masa Pandemi Covid-19
}

\author{
Elementary School Students Parents' Perceptions in the City of Gunungsitoli on Distance \\ Learning Policy during Covid-19 Pandemic
}

\section{Delipiter Lase' ${ }^{1}$ Amurisi Ndraha², Gustav Gabriel Harefa ${ }^{3}$}

123 STT Banua Niha Keriso Protestan Sundermann Nias | piterlase@sttsundermann.ac.id muris.ndraha@sttsundermann.ac.id, gustavharefa@sttsundermann.ac.id

\section{ARTICLE INFO}

Submitted: September 30, 2020

Review: October 8, 2020

Accepted: November 30, 2020

Published: December 12, 2020

\section{KEYWORDS}

Covid-19, distance learning, parents' perception, study from home

\section{CORRESPONDENCE}

Phone:

E-mail: piterlase@sttsundermann.ac.id

\begin{abstract}
A B S T R A C T
This study was developed to investigate parents' perceptions and attitudes towards distance learning in response to many schools' closure due to the Covid-19 pandemic - research using a qualitative approach. The study subjects consisted of parents of elementary school students in the City of Gunungsitoli who were determined by purposive sampling techniques, totaling twenty-four people. The data were collected using a semiconstructed interview and analyzed with thematic analysis. This study shows that distance learning or study from home in the research context is conducted online and offline. For parents, the learning approach imposed during the Covid-19 pandemic emergency must be lived and supported due to the absence of other options. Although parents do not have negative perceptions, distance learning has contributed to the growing burden of parenthood or family economically, psychologically, and socially. The lack of parental involvement and support in children's learning process at home is generally due to the lack of time and the inability of parents to become teachers for their children at home. The act of accompanying and supporting children's learning process at home is carried out to provide internet packages, help children master the material, and participate in completing tasks or tests given by teachers. The surprising findings of this study are the decrease in children's learning motivation and cognitive abilities. Parents hope that distance learning will not be extended for the rest of the 2020/2021 academic year so that children can learn again in educational institutions.
\end{abstract}

\begin{abstract}
A B S T R A K
Penelitian ini dikembangkan untuk menyelidiki persepsi dan sikap orang tua terhadap pembelajaran jarak jauh, sebagai respon atas penutupan banyak sekolah akibat pandemic Covid-19. Penelitian menggunakan pendekatan kualitatif. Subjek penelitian terdiri dari orang tua siswa sekolah dasar di Kota Gunungsitoli yang ditetapkan dengan teknik purposive sampling, berjumlah dua puluh empat orang. Data dijaring dengan menggunakan teknik wawancara semi-terstruktur dan dianalisis dengan teknik analisis tematik. Studi ini menunjukkan bahwa pembelajaran jarak jauh atau belajar dari rumah dalam konteks penelitian diselenggarakan dalam bentuk pembelajaran daring dan luring. Bagi orang tua, pendekatan pembelajaran yang diberlakukan pada masa darurat pandemi Covid-19 adalah sesuatu yang harus dijalani dan didukung karena ketiadaan pilihan lain. Meskipun orangtua tidak memiliki persepsi negatif, namun pembelajaran jarak jauh telah berkontribusi terhadap bertambahnya beban orangtua atau keluarga secara
\end{abstract}


ekonomi, psikologi dan sosial. Minimnya keterlibatan dan dukungan orang tua dalam proses belajar anak di rumah secara umum disebabkan oleh ketiadaan waktu dan ketidakmampuan orang tua menjadi guru bagi anak-anaknya di rumah. Tindakan mendampingi dan mendukung proses belajar anak di rumah dilakukan dalam bentuk penyediaan paket internet, membantu anak menguasai materi, dan ikut serta menyelesaikan tugas atau tes yang diberikan oleh guru. Temuan yang mengejutkan dari penelitian ini adalah menurunnya motivasi belajar dan kemampuan kognitif anak. Oang tua berharap agar pembelajaran jarak jauh tidak diperpanjang pada sisa tahun pelajaran 2020/2021, sehingga anak-anak boleh belajar kembali di institusi pendidikan.

Kata kunci: orang tua siswa, pandemi Covid-19, pembelajaran jarak jauh, persepsi

\section{PENDAHULUAN}

$\mathbf{P}$ andemi Covid-19 telah menyebabkan perubahan pola interaksi dan beraktivitas dalam hampir seluruh aspek kehidupan manusia tak terkecuali sektor pendidikan. Terkait dengan pendidikan, pandemi Covid-19 telah mengganggu kehidupan siswa dengan berbagai cara, dan ini merupakan tantangan khusus bagi peserta didik. Mereka tidak akan dapat menyelesaikan kurikulum dan penilaian sekolah mereka dengan cara normal, dan mereka juga telah dipisahkan dari kelompok sosial mereka. Setuju tidak setuju, sekolah harus menyesuaikan manajemen pembelajaran, beralih dari kelas kovensional ke pembelajaran jarak jauh baik daring maupun luring, meskipun pada beberapa daerah tertentu di Indonesia sekolah masih menerapkan pembelajaran konvensional (tatap muka) khususnya di daerah yang belum terdampak pandemi Covid-19.

Data per 20 Agustus, UNESCO (2020) mencatat 673.114.704 pelajar yang terdampak, $38.4 \%$ dari total pelajar terdaftar, serta sebanyak 30 negara menutup seluruh sekolah di negaranya. Sebagian besar pemerintah di seluruh dunia telah menutup sementara lembaga pendidikan dalam upaya untuk menahan penyebaran pandemi Covid-19. Penutupan nasional ini berdampak pada lebih dari $60 \%$ populasi siswa dunia. Beberapa negara lain telah

1 UNESCO, "School Closures Caused by Coronavirus (Covid-19)," Unesco, 2020, accessed June 2, 2020, https://en.unesco.org/covid19/educationresponse.

2 Ratna Puspita, "Kemendikbud: 68 Juta Siswa Terdampak Pandemi Covid-19," REPUBLIKA.Co.Id (Jakarta, August 4, 2020), https://republika.co.id/ berita/qejb7r428/kemendikbud-68-juta-siswaterdampak-pandemi-covid19. menerapkan penutupan lokal yang berdampak pada jutaan pelajar tambahan. ${ }^{1}$

Di Indonesia, Kementerian Pendidikan dan Kebudayaan mengemukakan bahwa sebanyak 68 juta lebih peserta didik mulai dari tingkat pendidikan anak usia dini (PAUD) hingga sekolah menengah atas (SMA) di Indonesia turut terdampak pandemi Covid-19. Mereka terpaksa belajar dari rumah akibat pandemi Covid-19.2 Dari jumlah tersebut "hanya sekitar 34,5 persen yang bisa mengakses layanan pendidikan online," ujar Abdul Fikri Faqih (Wakil Ketua Komisi X DPR) dalam Viva (2020). ${ }^{3}$

Merespon penutupan sebagian besar sekolah di Indonesia, Pemerintah Indonesia melalui Kementerian Pendidikan dan Kebudayaan menerbitkan surat Edaran No. 4 Tahun 2020 tanggal 24 Maret 2020 tentang Kebijakan Nasional Pendidikan pada masa darurat pademi Covid-19. Dalam edaran tersebut dijelaskan bahwa proses belajar mengajar dilaksanakan di rumah melalui pembelajaran jarak jauh (PJJ). Buntut dari kebijakan nasional tersebut, 646.200 sekolah ditutup mulai dari jenjang pendidikan anak usia dini hingga perguruan tinggi. Akibatnya, 68,8 juta siswa belajar di rumah dan 4,2 juta guru dan dosen mengajar dari rumah. ${ }^{4}$ Terkait dengan kebijakan ini, survei yang dilakukan Kementerian Pendidikan dan Kebudayaan pada April 2020 menunjukkan 97,6 persen sekolah telah

3 Viva, "Terdampak Corona, 34,5 Persen Pelajar Indonesia Tak Terakses Pendidikan Online," Suara Merdeka (Jakarta, April 4, 2020), https://www.suaramerdeka.com/news/nasional/224640-terdampakcorona-345-persen-pelajar-indonesia-tak-teraksespendidikan-online.

${ }^{4}$ Anisyah Al Faqir, "Kemendikbud Catat 646.200 Sekolah Tutup Akibat Virus Corona," 2020, https://www.merdeka.com/uang/kemendikbudcatat-646200-sekolah-tutup-akibat-virus-corona.html. 
melaksanakan kegiatan belajar dari rumah, dan menyisakan 2,4 persen sekolah lainnya tetap menjalankan kegiatan belajar-mengajar di institusi pendidikan.

Menindak-lanjuti SE No. 4 Tahun 2020, Kemendikbud menerbitkan SE Nomor 15 Tahun 2020 tentang Pedoman Penyelenggaraan Belajar dari Rumah (BDR) dalam Masa Darurat Penyebaran Covid-19. Surat edaran ini ditujukan untuk (1) memastikan pemenuhan hak peserta didik untuk mendapatkan layanan pendidikan selama darurat Covid-19; (2) melindungi warga satuan pendidikan dari dampak buruk Covid-19; (3) mencegah penyebaran dan penularan Covid19 di satuan pendidikan; dan (4) memastikan pemenuhan dukungan psikososial bagi pendidik, peserta didik dan orang tua atau wali.

Belajar dari rumah merupakan istilah lain dari model pembelajaran jarak jauh yang dikembangkan di Indoensia. Dilaksanakan melalui dua pendekatan, yakni (1) PJJ dalam jaringan (daring), dan (2) PJJ luar jaringan (luring) (Kemendikbud, 2020). Khusus untuk pembelajaran luring, dimaknai lebih luas dari sekedar pembelajaan tradisional di era sebelum internet, di mana proses belajar mengajar harus dilakukan pada waktu dan tempat yang sama. ${ }^{5}$ Dalam Pembelajaran luring ini siswa belajar melalui sumber belajar fisik seperti buku siswa, pedoman guru, modul, lembar kerja peserta didik (LKPD). Dalam model ini juga, siswa dapat mengakses konten-konten pelajaran melalui siaran TVRI dan Radio.

Pemberlakuan pembelajaran jarak jauh untuk memastikan pendidikan tetap berjalan serta menghambat penyebaran pandemic Covid19, bukan berarti tidak menghadapi tantangan

5 Leisi Pei and Hongbin $\mathrm{Wu}$, "Does Online Learning Work Better than Offline Learning in Undergraduate Medical Education? A Systematic Review and Meta-Analysis," Medical Education Online 24, no. 1 (January 1, 2019): 1666538, https://www. tandfonline.com/doi/full/10.1080/10872981.2019.16 66538.

6 Priarti Megawanti, Erna Megawati, and Siti Nurkhafifah, "Persepsi Peserta Didik Terhadap PJJ Pada Masa Pandemi Covid 19," Faktor Jurnal Ilmiah Kependidikan 7, no. 2 (2020): 75-82.

7 Haris Nursyah Arifin, "Respon Siswa Terhadap Pembelajaran Dalam Jaringan Masa Pandemi COVID-19 Di Madrasah Aliyah Al-Amin Tabanan," WIDYA BALINA: Jurnal Ilmu Pendidikan dan dan kendala. Selain manfaat positif seperti mempercepat integrasi teknologi, informasi dan komunikasi dalam kegiatan pembelajaran, juga terdapat beberapa kendala yang dihadapi. Di antaranya, guru dan siswa, belum terbiasa menggunakan sistem pembelajaran yang diracik dan sepenuhnya online, karena itu diperlukan dukungan dan pendampingan tambahan untuk menyesuaikan dengan model pembelajaran baru tersebut.

Beberapa temuan penelitian sebelumnya mengindikasi bahwa siswa pada umumnya lebih senang dan menyukai belajar tatap muka di kelas daripada belajar di rumah dengan pembelajaran online (e-learning), dengan alasan lebih mudah memahami materi ketika guru menjelaskan secara langsung (tatap muka). Di kelas lebih bisa berinteraksi dan belajar bersama. ${ }^{6}$ Belajar di rumah terkendala karena keterbatasan kuota internet. ${ }^{7}$ Hanya 56\% yang menyatakan kepuasannya dengan penerapan e-learning. ${ }^{8}$ $78,6 \%$ responden merasa bahwa kelas konvensional lebih efektif dibandingkan dengan pembelajaran online. ${ }^{9}$ Meskipun tidak menyukai, namun pada hasil-hasil penelitian terdahulu itu, responden penelitian setuju apabila pembelajaran online adalah solusi yang tepat pada masa krisis ini.

Selain itu, para guru mengalami peningkatan pengeluaran untuk pembelian kuota; lelah dan bosan tinggal di rumah dan ingin kembali ke sekolah untuk segera berinteraksi dengan siswa. Butuh waktu yang banyak, bahkan bekerja hingga larut malam untuk menyiapkan bahan pembelajaran dan memberi umpan balik; tidak dapat memonitoring kemajuan belajar peserta didik. ${ }^{10}$

Ekonomi 5, no. 9 (2020): 1-12, https://journal.staidenpasar.ac.id/index.php/wb/article/view/47.

8 Kriswanda Krishnapatria, "From 'Lockdown' to Letdown: Students' Perception of E-Learning amid the COVID-19 Outbreak," ELT in Focus 3, no. 1 (2020): 1-8, https://journal.unsika.ac.id/index.php/ELTINFOCUS/article/view/3694.

9 Muhammad Adnan and Kainat Anwar, "Online Learning amid the COVID-19 Pandemic: Students' Perspectives," Journal of Pedagogical Sociology and Psychology 2, no. 1 (2020): 45-51, https://www.jpsp.com/article/online-learning-amid-the-covid-19pandemic-students-perspectives- 8355 .

10 Ratna Setyowati Putri et al., "Impact of the COVID-19 Pandemic on Online Home Learning: An 
Guru bekerja hingga larut malam dan akhir pekan untuk mengembangkan materi dan mendukung pembelajaran online siswa mereka. ${ }^{11}$

Bagaimana dengan orang tua? Orang tua memiliki kemampuan yang terbatas dalam menyediakan fasilitas pembelajaran online bagi anak-anak.12 Produktivitas ekonomi menurun karena orang tua harus mengasuh anak sambil bekerja. ${ }^{13}$ Ketika rumah tangga terkurung di tempat tinggal mereka oleh Covid-19, orang tua dan wali mungkin sangat cemas tentang masa depan ekonomi mereka sendiri, jadi belajar di rumah tidaklah mudah, terutama untuk anakanak dengan motivasi rendah. ${ }^{14}$ Pembelajaran online memerlukan koneksi internet yang karenanya telah menambah pengeluaran orang tua. 15

Berangkat dari uraian di atas, penelitian ini ditujukan untuk menyelidiki bagaimana satuan pendidikan khususnya jenjang pendidikan sekolah dasar menerapkan pembelajaran jarak jauh (belajar dari rumah) pada masa pandemi Covid-19. Selain itu, penelitian ini juga bertujuan untuk memeroleh gambaran tentang persepsi dan sikap orang tua terhadap pembelajaran jarak jauh serta tindakan mereka dalam mendukung studi anak-anak mereka.

Masalah ini menjadi objek penelitian dengan beberapa alasan, di antaranya penelitianpenelitian sebelumnya memfokuskan diri pada penyelidikan kesiapan guru dalam melakoni pembelajaran jarak jauh serta ditujukan untuk memeroleh gambaran tentang persepsi guru, siswa dan efektivitas pembelajaran jarak jauh. Di sisi lain, hingga pekerjaan ini dimulai pada awal Agustus 2020, penelitian tentang bagaimana persepsi orang tua teradap pelaksanaan

Explorative Study of Primary Schools in Indonesia," International Journal of Advanced Science and Technology 29, no. 05 (2020): 4809-4818, http://sersc.org/ journals/index.php/IJAST/article/view/13867.

11 Petar Jandrić, "Postdigital Research in the Time of Covid-19," Postdigital Science and Education 2, no. 2 (April 21, 2020): 233-238, http://link.springer. com/10.1007/s42438-020-00113-8.

${ }_{12}$ Luh Devi Herliandry et al., "Pembelajaran Pada Masa Pandemi Covid-19" 22, no. 1 (2020): 65-70, http://journal.unj.ac.id/unj/index.php/jtp.

13 Zaharah Zaharah and Galia Ildusovna Kirilova, "Impact of Corona Virus Outbreak Towards Teaching and Learning Activities in Indonesia," SALAM: Jurnal Sosial dan Budaya Syar-i 7, no. 3 (March pembelajaran jarak jauh khususnya di wilayah pedalaman Indonesia, belum banyak disentuh oleh para peneliti.

\section{METODE}

Penelitian ini mengambil lokasi di Kota Gunungsitoli. Kota Gunungsitoli merupakan salah satu dari 514 Kabupaten/Kota di Indonesia. Secara geografis berada di daerah kepulauan yakni Pulau Nias dan menjadi bagian dari 34 kabupaten/kota di provinsi Sumatera Utara. Meskipun kota ini secara administratif pemerintahan masuk dalam kategori 'kota', namun karena letak geografisnya di wilayah kepulauan - daerah ini termasuk wilayah di mana sekitar $65,5 \%$ peserta didiknya tidak bisa mengakses layanan pendidikan online.

Dalam hal pendidikan, kota ini memiliki 186 satuan pendidikan yang terdiri dari 115 satuan pendidikan SD/sederajat, 40 $\mathrm{SMP} /$ sederajat, $17 \mathrm{SMA} /$ sederajat dan 14 $\mathrm{SMK} /$ sederajat. Penelitian ini mengambil subjek Sekolah Dasar, dimana pada jenjang pendidikan ini Kota Gunungsitoli memiliki jumlah peserta didik sebanyak 18.213 yang menyebar pada 115 $\mathrm{SD} /$ sederajat.

Hingga Agustus 2020, berdasarkan tingkat penyebaran pandemi Covid-19, Kota Gunungsitoli berada di zona hijau. Zona di mana sekolah dapat dimungkinkan untuk menyelenggarakan pembelajaran tatap muka dengan pembatasan-pembatasan tertentu.

Penelitian ini menggunakan jenis penelitian deskriptif kualitatif. Menurut Moleong, penelitian kualitatif adalah penelitian yang bermaksud untuk memahami fenomena tentang apa yang dialami oleh subjek penelitian. ${ }^{16}$

26, 2020), http://journal.uinjkt.ac.id/index.php/ salam/article/view/15104.

14 Alexander Skulmowski and Günter Daniel Rey, "COVID-19 as an Accelerator for Digitalization at a German University: Establishing Hybrid Campuses in Times of Crisis," Human Behavior and Emerging Technologies 2, no. 3 (2020): 212-216.

15 Wahyu Aji Fatma Dewi, “Dampak COVID-19 Terhadap Implementasi Pembelajaran Daring Di Sekolah Dasar," EDUKATIF: JURNAL ILMU PENDIDIKAN 2, no. 1 (2020): 55-61, https://edukatif.org/index.php/edukatif/article/vie $\mathrm{w} / 89$.

${ }^{16}$ Lexy J. Moleong, Metodologi Penelitian Kualitatif (Bandung: PT Remaja Rosdakarya, 2012), 6. 
Pertimbangan untuk memilih pendekatan kualitatif adalah di antaranya penelitian hendak menyelami kedalaman kompleksitas dan proses; variabel terkait belum teridentifikasi. ${ }^{17}$ Sumber data dan informan (partisipan) terdiri dari orang tua siswa kelas 4-6 sekolah dasar di wilayah Kota Gunungsitoli. Selain pertimbangan wilayah geografis, partisipan (Tabel 1) berjumlah 24 (dua puluh empat) orang ditetapkan dengan menggunakan teknik purpose sampling, yakni didasarkan atas kompetensi dan bukan atas dasar keterwakilan. ${ }^{18}$

Data dijaring dengan menggunakan teknik wawancara semi terstruktur. ${ }^{19}$ Wawancara dilakukan secara tatap muka dan percakapan dengan telepon. Wawancara tatap muka maupun melalui percakapan telepon berlangsung selama tiga minggu, dari tanggal 3 22 Agustus 2020 dengan durasi waktu 10-15 menit per partisipan.

Analis data dilakukan dengan menggunakan thematic analysis, merupakan salah satu cara untuk menganalisa data dengan tujuan untuk mengidentifikasi pola atau untuk menemukan tema melalui data yang telah terkumpul. ${ }^{20}$

Tabel 1. Karakteristik Partisipan (Responden)

\begin{tabular}{ccclll}
\hline Nama & Usia & L/P & Pendidikan & Pekerjaan & Alamat \\
\hline$R_{1}$ & 42 & $\mathrm{~L}$ & Sarjana & ASN/PNS & Gunungsitoli Idanoi \\
\hline $\mathrm{R}_{2}$ & 40 & $\mathrm{~L}$ & SLTP & Petani/Nelayan & Gunungsitoli Idanoi \\
\hline $\mathrm{R}_{3}$ & 38 & $\mathrm{P}$ & SLTA & Wiraswasta & Gunungsitoli Idanoi \\
\hline $\mathrm{R}_{4}$ & 39 & $\mathrm{~L}$ & SD & Buruh Harian & Gunungsitoli Idanoi \\
\hline $\mathrm{R}_{5}$ & 40 & $\mathrm{P}$ & SLTA & Pegawai Swasta & Gunungsitoli Idanoi \\
\hline $\mathrm{R}_{6}$ & 43 & $\mathrm{~L}$ & Sarjana & ASN/PNS & Gunungsitoli Alo'oa \\
\hline $\mathrm{R}_{7}$ & 40 & $\mathrm{P}$ & SD & Petani & Gunungsitoli Alo'oa \\
\hline $\mathrm{R}_{8}$ & 40 & $\mathrm{~L}$ & Sarjana & ASN/PNS & Gunungsitoli \\
\hline $\mathrm{R}_{9}$ & 47 & $\mathrm{P}$ & Sarjana & ASN/PNS & Gunungsitoli \\
\hline $\mathrm{R}_{10}$ & 38 & $\mathrm{~L}$ & SLTP & Petani/Nelayan & Gunungsitoli \\
\hline $\mathrm{R}_{11}$ & 38 & $\mathrm{~L}$ & SD & Petani/Nelayan & Gunungsitoli \\
\hline $\mathrm{R}_{12}$ & 40 & $\mathrm{~L}$ & SD & Buruh Harian & Gunungsitoli \\
\hline $\mathrm{R}_{13}$ & 39 & $\mathrm{~L}$ & SLTP & Buruh Harian & Gunungsitoli \\
\hline $\mathrm{R}_{14}$ & 43 & $\mathrm{P}$ & Sarjana & Wiraswasta & Gunungsitoli \\
\hline $\mathrm{R}_{15}$ & 39 & $\mathrm{P}$ & Sarjana Muda & Pegawai Swasta & Gunungsitoli \\
\hline $\mathrm{R}_{16}$ & 41 & $\mathrm{~L}$ & Sarjana & ASN/PNS & Gunungsitoli Selatan \\
\hline $\mathrm{R}_{17}$ & 39 & $\mathrm{~L}$ & SLTP & Petani/Nelayan & Gunungsitoli Selatan \\
\hline $\mathrm{R}_{18}$ & 42 & $\mathrm{P}$ & Sarjana Muda & Wiraswasta & Gunungsitoli Selatan \\
\hline $\mathrm{R}_{19}$ & 41 & $\mathrm{~L}$ & Sarjana & ASN/PNS & Gunungsitoli Barat \\
\hline $\mathrm{R}_{20}$ & 40 & $\mathrm{~L}$ & SLTP & Petani & Gunungsitoli Barat \\
\hline $\mathrm{R}_{21}$ & 38 & $\mathrm{P}$ & Sarjana & ASN/PNS & Gunungsitoli Utara \\
\hline $\mathrm{R}_{22}$ & 40 & $\mathrm{~L}$ & SLTP & Petani/Nelayan & Gunungsitoli Utara \\
\hline $\mathrm{R}_{23}$ & 39 & $\mathrm{P}$ & SLTA & Wiraswasta & Gunungsitoli Utara \\
\hline $\mathrm{R}_{24}$ & 40 & $\mathrm{~L}$ & SLTP & Buruh Harian & Gunungsitoli Utara \\
\hline & & & & & \\
\hline
\end{tabular}

17 Catherine Marshall and Gretchen B. Rossman, Designing Qualitative Research, 6th ed. (Thousand Oaks, CA: SAGE Publications, Inc., 2015), 46.

18 H Russell Bernard and Bernard H. Russell, Reserach Methods in Anthropology - Qualitative and Quantitative Approaches, AltaMira Press (Walnut Creek: AltaMira Press, 2006).

${ }^{19}$ Ibid.
20 Heriyanto Heriyanto, "Thematic Analysis Sebagai Metode Menganalisa Data Untuk Penelitian Kualitatif," Anuva 2, no. 3 (November 22, 2018): 317, https://ejournal2.undip.ac.id/index.php/anuva/arti cle/view/3679; Virginia Braun and Victoria Clarke, "Using Thematic Analysis in Psychology," Qualitative Research in Psychology 3, no. 2 (January 2006): 77-101, http:/ / www.tandfonline.com/doi/abs/10.1191/147 8088706qp063oa. 


\section{HASIL PENELITIAN}

\section{Penerapan PJJ di Wilayah Kota Gunungsitoli}

Dari 24 orang tua yang diwawancara, terdapat 9 responden $(37,5 \%)$ menyatakan bila anak-anak mereka belajar dari rumah dalam bentuk pembelajaran daring (online). Orang tua lebih memilih pendekatan ini karena kuatir anakanak terpapar Covid-19.

\begin{abstract}
"Kami kuatir, anak-anak menjadi korban penyebaran pandemi Covid-19. Meskipun pembelajaran luring (offline) diterapkan, kami lebih memilih pendekatan daring (online). Semua konten pelajaran atau LKPD termasuk tugas dan ulangan harian dikirim kepada anakanak melalui media sosial (WhatsApp). Kemudian, materi atau tugas yang telah diselesaikan anak-anak diserahkan kembali ke wali kelas atau guru bidang studi apakah dalam bentuk dokumen, video dan podscat. Materi yang kurang dipahami oleh anak-anak, biasanya didiskusikan melalui grup WA kelas atau langsung kepada guru bidang studi." (R8 dan $\left.R_{9}\right)$.
\end{abstract}

Berbeda dengan kesembilan responden di atas, 15 orang $(62,5 \%)$ dari total responden mengatakan bahwa anak-anak belajar dari rumah dalam bentuk pembelajaran luring (offline). Adapun pertimbangan pemilihan ini, di antaranya terkait dengan masalah jaringan yang kurang stabil dan ketiadaan perangkat atau peralatan pendukung aktivitas belajar anak di rumah.

\begin{abstract}
"Oleh karena berbagai keterbatasan, di antaranya jaringan yang kurang stabil, minimnya peralatan teknis belajar anak seperti laptop, tablet atau ponsel, printer dan lainnya, termasuk ketiadaan biaya paket internet dan kemampuan mengoperasikan perangkat lunak yang dipersyaratkan. Pada akhirnya kami lebih memilih anak-anak belajar di rumah dalam bentuk pembelajaran luring (offline). Setiap awal minggu, orang tua menjemput LKPD dan mengantarnya kembali ke sekolah sesuai jadwal yang telah ditentukan oleh wali kelas atau guru bidang studi." ( $\mathrm{R}_{7}$, $\mathrm{R}_{13}$ dan $\mathrm{R}_{22}$ ).
\end{abstract}

Temuan penelitian di atas terkonfirmasi oleh pejabat pemerintah pada bagian Pendidikan Dasar Dinas Pendidikan Kota Gunungsitoli. Dikatakan bahwa PJJ pada jenjang pendidikan sekolah dasar dilakukan dengan pendekatan daring dan luring. Dinas Pendidikan Kota Gunungsitoli belum dapat menerapkan pembelajaran jarak jauh secara daring penuh karena letak geografis sekolah - lebih banyak berada di wilayah kecamatan dan desa. Di wilayah ini sulit ditemukan infrastruktur telekomuniasi yang memadai dengan jaringan yang stabil.

\section{Persepsi Orang Tua tentang PJJ}

Persepsi orang tua tentang pembelajaran jarak jauh pada masa krisis ini adalah bervariasi. Sulit menemukan pernyataan yang tegas antar setuju atau tidak setuju; suka dan tidak suka. Meskipun demikian, orang tua secara umum tidak memiliki pandangan yang negatif atau penolakan terhadap penerapan PJJ, namun bagi orang tua, ini adalah sesuatu yang tidak diharapkan, hal baru, membebani dan memaksa untuk menyesuaikan diri secara cepat.

".... ini rumit, anak-anak dan termasuk kami para orang tua belum punya pengalaman dengan manajemen pembelajaran jarak jauh yang diterapkan saat ini. Tetapi, ya... anakanak juga tidak memiliki pilihan lain - mau tak mau anak-anak harus melakoni model pembelajaran yang baru ini. Meskipun sekolah ditutup, akan tetapi proses pembelajaran tentunya tidak mungkin dihentikan terusmenerus dalam waktu yang tidak dapat diprediksi." $\left(\mathrm{R}_{3}, \mathrm{R}_{10}\right.$ dan $\left.\mathrm{R}_{20}\right)$.

Penyebaran pandemi Covid-19 merupakan situasi yang belum pernah terjadi sebelumnya, hal ini telah membuat mayoritas orang tua kuatir tentang dampak negatif pandemi terhadap pendidikan anak. Meskipun demikian, yang memrihatinkan, tetap saja ada orang tua $(22 \%)$ yang tidak terlalu peduli dengan dampak Covid19 terhadap pendidikan anak-anaknya.

\section{Keterlibatan Orang Tua dalam Pembelajaran Anak di Rumah}

Ibu sebagai pengasuh utama (dalam kebanyakan kasus) menunjukkan perannya mendukung pendidikan dan pembelajaran anak. Hasil wawancara menunjukkan 13 (tiga belas) orang tua $(54,17 \%)$ memberi waktu meskipun terbatas untuk terlibat dengan pembelajaran anak-anak di rumah. Sebanyak 7 atau $29.17 \%$ orang tua secara meyakinkan mengaku memiliki 
waktu luang yang banyak untuk mendampingi kegiatan belajar anak di rumah. Sisanya, adalah orang tua yang sangat sibuk sehingga jarang memonitoring aktivitas belajar anak di rumah dan/atau menyerahkan pendampingan aktivitas belajar anak kepada anggota keluarga lainnya (Gambar 1).

"Waktu terbaik kami mendampingi anak-anak belajar ini adalah di malam hari, karena pagi hingga sore hari kami harus bekerja, dan ini waktunya relatif singkat karena anak terbiasa tidur cepat pada malam hari." ( $\mathrm{R}_{5}$ dan $\left.\mathrm{R}_{15}\right)$

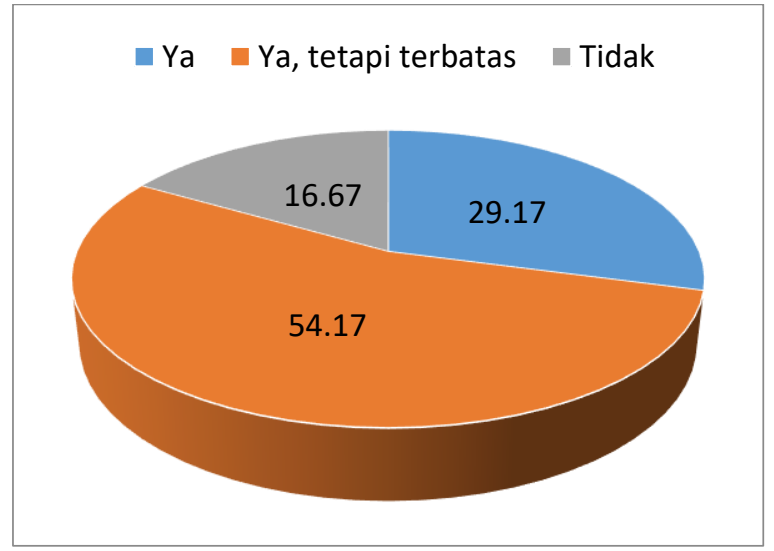

Gambar 1.

Ketersediaan waktu orang tua mendampingi aktivitas belajar anak-anak di rumah

"Kebetulan saya dan ibunya anak-anak bekerja sebagai ASN, sehingga aktivitas belajar anak di rumah lebih banyak didampingi oleh anggota keluarga lain. Kecuali pada malam hari, saya dan/atau ibu mengecek bahan pelajaran dan tugas-tugas yang wajib diselesaikan oleh anakanak." ( $\mathrm{R}_{8}$, dan $\left.\mathrm{R}_{16}\right)$

"Saya lebih banyak terlibat dalam pembelajaran anak di rumah itu pada pagi hari. Sehingga, pada sore atau malam hari, anak-anak lebih banyak istrahat dan/atau bermain." $\left(\mathrm{R}_{14}\right)$

Ketika ditanya apakah mereka dapat atau merasa mampu mendukung anak-anak di rumah dalam hal belajar. $34,4 \%$ merasa dapat dan memiliki kemampuan mendukung studi anak mereka di rumah. 65,6\% lainnya tampak raguragu dan berusaha dengan kemampuan yang terbatas (Gambar 2).

"Anak saya bersekolah di SD Swasta Kristen BNKP Gunungsitoli dan duduk di kelas 5. Setiap minggu anak-anak menerima 5-7 LKPD. Sejauh ini belum ada kendala, materi dan soal-soal yang kurang dipahami oleh anak-anak, kami jelaskan dengan baik, terkadang harus berulang agar anak lebih mengerti. Tetapi, tentu saja metode yang kami gunakan tidak sebaik metode mengajar guru di sekolah." ( $\mathrm{R}_{15}$ dan $\left.\mathrm{R}_{16}\right)$

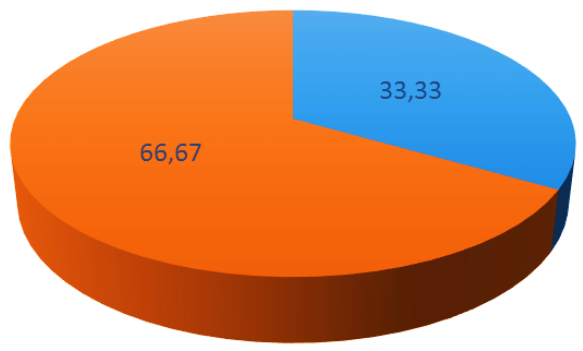

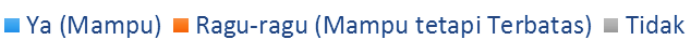

Gambar 2.

Kemampuan mendukung studi anak-anak di rumah

"Kalau dikatakan mampu, sesungguhnya tidak. Karena, kalau mampu buat apa orang tua stres, lalu suka marah-marah. Anak-anak di rumah itu tidak mau belajar bila tidak diingatkan dan diawasi. Susahnya, anak-anak lebih hormat (takut) kepada gurunya di sekolah dari pada orang tua di rumah. Agak kurang pahamlah, apakah ini kelemahan orang tua pada umumnya - ada pandangan di kalangan orang tua bahwa urusan pendidikan adalah urusan sekolah." ( $\left.\mathrm{R}_{11} \& \mathrm{R}_{19}\right)$.

Hasil wawancara dengan orang tua lainnya, menunjukkan bahwa pembelajaran jarak jauh ini berpotensi memicu kekerasan terhadap anak di rumah. Ada orang tua mengaku bila "Anak-anak di rumah tidak mau belajar kalau tidak disuruh, sudah begitu - materi dan tugas yang diberikan dari sekolah juga susah dipahami oleh anak, akibatnya orang tua marah-marah dan tak jarang berperilaku kasar atau keras hingga ke pemukulan." ( $\left.\mathrm{R}_{17}\right)$.

\section{Tindakan dan dukungan orang tua terhadap aktivitas belajar anak di rumah}

Beralih dari persepsi aktual orang tua ke tindakan, diperoleh informasi bahwa terdapat $70,83 \%$ dari mereka selalu memeriksa atau memonitoring lembar kerja peserta didik (LKPD) dari sekolah. Lebih $65 \%$ orang tua mendukung aktivitas pembelajaran anak-anak di rumah dalam bentuk penyediaan paket internet; membantu menjelaskan dan menyelesaikan lembar kerja peserta didik (LKPD). 16,67\% mendukung pendidikan dan pembelajaran anak 
dalam bentuk penyediaan peralatan (seperti telepon seluler, tablet, laptop). Dan, kurang dari $10 \%$ dalam bentuk belajar privat dan atau kursus (Gambar 3). untuk membuka kembali satuan pendidikan ada tahun ajaran baru Juli 2020. Kebijakan ini hanya berlaku pada wilayah yang tingkat penyebaran Covid-19 cukup rendah (zona hijau dan kuning).

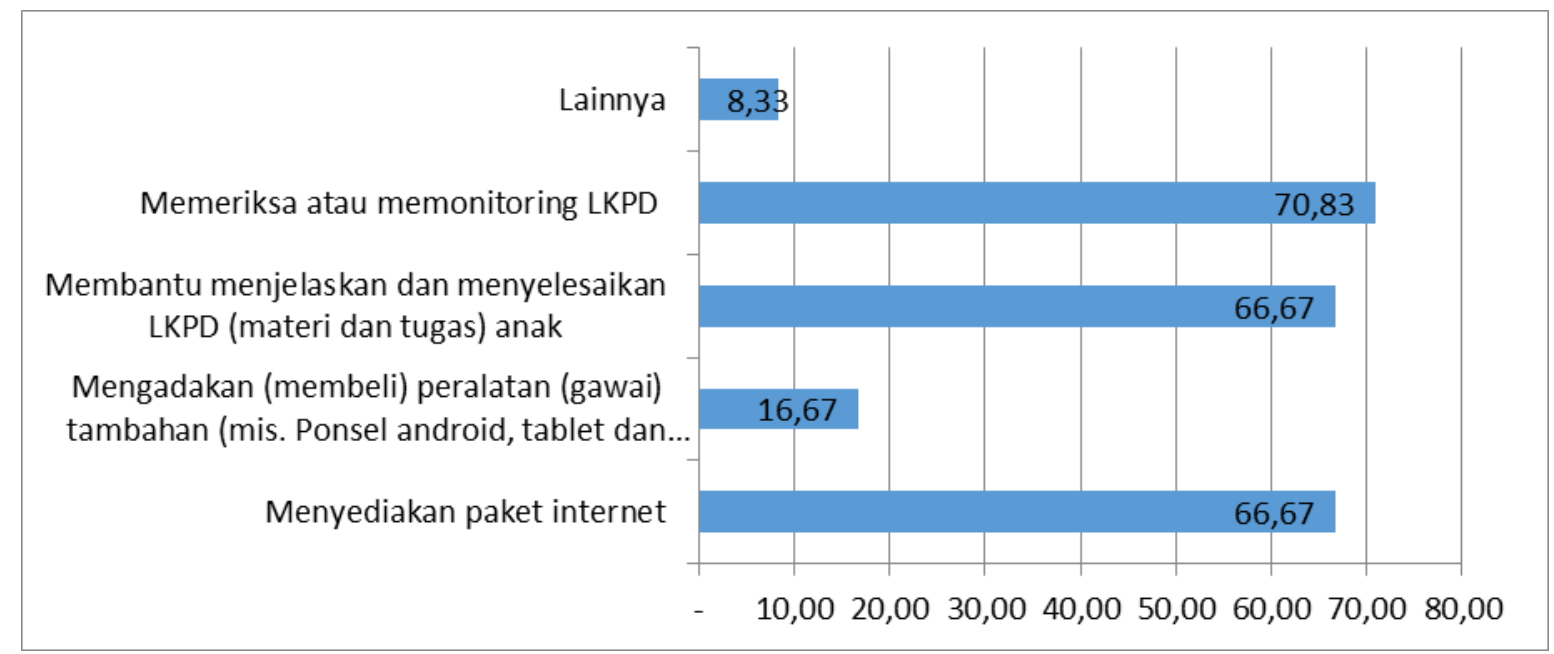

Gambar 3. Tindakan orang tua terhadap aktivitas pembelajaran anak di rumah

“...... tidak banyak hal yang dilakukan, selain penyediaan paket internet, kami membantu anak-anak menjelaskan materi yang kurang dipahami dan turut serta menyelesaikan tugas atau soal ujian yang diberikan dari sekolah. Di atas semua itu - kami mengawasi interaksi mereka terhadap orang lain selain keluarga guna menjaga kemungkinan mereka terjangkit Covid-19." ( $\left.\mathrm{R}_{5}\right)$

Pandemi Covid-19 telah memaksa penutupan hampir semua sekolah di Indonesia. Untuk memastikan proses pendidikan terus berlanjut, Kemendikbud menempuh kebijakan
Sementara di zona merah dan oranye sekolah tetap ditutup. Gambar berikut menunjukkan hambatan dan tantangan yang dihadapi orang tua atas pelaksanaan pembelajaran jarak jauh.

\section{Hambatan dan tantangan yang dihadapi orang tua terhadap pelaksanaan PJJ}

Penyelenggaran pendidikan dengan pendekatan pembelajaran jarak jauh baik daring maupun luring, tidak berarti tidak ada kendala atau tantangan. Lebih $54,4 \%$ orang tua mengeluhkan peningkatan biaya pendidikan anak-anak, 41,9\% merasa tertekan, stres dan

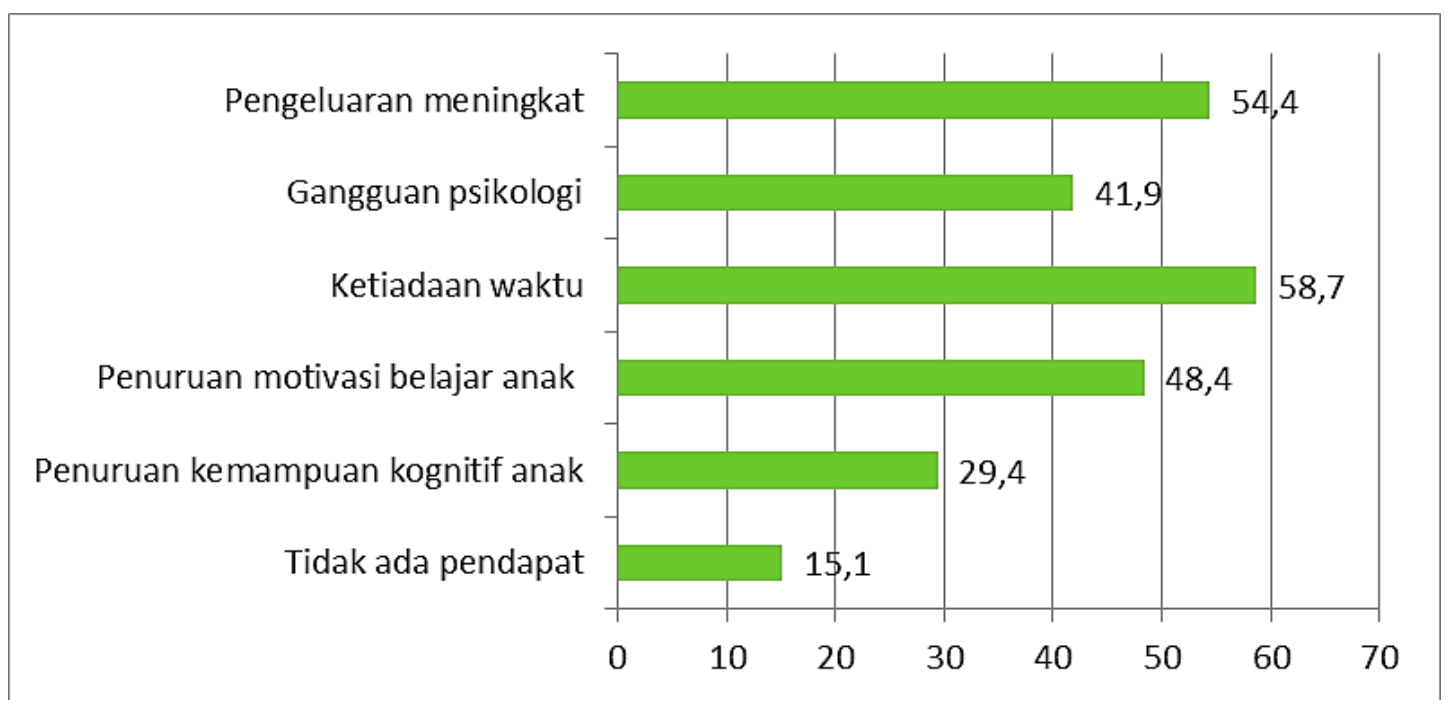

Gambar 4.

Kendala dan tantangan yang dihadapi orang tua terhadap pembelajaran jarak jauh 
frustasi karena meningkatnya beban pikiran dan pekerjaan mereka. 58,7\% orang tua mengalami kesulitan mengatur waktu antara mendampingi anak belajar dengan pekerjaan sehari-hari (tugas pokok). Hal yang memrihatinkan adalah $48,45 \%$ orang tua mengaku bila motivasi belajar anak mereka semakin menurun dan $29,4 \%$ orang tua merasa kemampuan kognitif anaknya, juga mengalami penurunan (Gambar 4).

"Biaya pendidikan anak-anak bertambah, pengeluaran menjadi lebih besar. Kami harus membeli paket internet agar anak-anak bisa akses sumber belajar secara online. Kami juga terpaksa membeli gawai (handphone) baru agar anak-anak dapat mengikuti pembelajaran secara daring." ( $\mathrm{R}_{4}$ dan $\left.\mathrm{R}_{9}\right)$.

“..... tidak hanya itu, pada pembelajran jarak jauh ini - motivasi belajar anak-anak pun menurun, kalau tidak diawasi mereka malah menghabiskan waktu dan paket untuk main game. Tak jarang kami menjadi stres dan frustasi melihat anak-anak tidak mau belajar dan kemampuan berpikirnya malah menurun mereka sulit memahami materi yang diberikan oleh guru melalui LKPD." ( $\mathrm{R}_{2}, \mathrm{R}_{12}$ dan $\left.\mathrm{R}_{23}\right)$

\section{Preferensi orang tua untuk pembelajaran di sisa tahun ajaran 2020/2021}

Terlepas dari kekuatiran mereka atas dampak negatif pandemi Covid-19 terhadap pendidikan anak, kebanyakan orang tua $(78,21 \%)$ tidak menginginkan pembelajaran jarak jauh ini diperpanjang dan berharap pemerintah membuka kembali sekolah-sekolah pada sisa tahun ajaran 2020/2021.

"Tak dapat dipungkiri, bahwa PJJ ini sangat
membebani, gangguan psikososial semakin
meningkat, terutamabagi anak-anak. Motivasi
belajar dan kemampuan kognitif anak
cenderung menurun. Kekuatiran kami adalah
kekerasan terhadap anak-anak di rumah
berpotensi menimgkat, tak jarang orang tua
marah-marah dan bahkan main pukul karena
anak-anak malas belajar dan tidak bisa

${ }^{21}$ Riska Febrianti, "Implementasi Kurikulum Dan Pembelajaran Di Masa Pandemi Covid-19," Universitas Negeri Malang, last modified 2020, accessed July 15, 2020, https://um.ac.id/berita/implementasikurikulum-dan-pembelajaran-di-masa-pandemicovid-19/. menyelesaikan tugas-tugas yang diberikan dari sekolah. Karena itu, kami mengharapkan agar pembelajaran jarak jauh ini segera diakhiri. Untuk sisa tahun pelajaran 2020/2021, agar pemerintah dapat membuka kembali institusi pendidikan sehingga proses pembelajaran dapat berlangsung seperti sedia kala, yakni pembelajaran tatap muka di kelas." $\left(\mathrm{R}_{1}, \mathrm{R}_{6}, \mathrm{R}_{18}\right.$ dan $R_{24}$ ).

Lebih lanjut, mereka berharap jika PJJ masih berlangsung untuk beberapa waktu ke depan, perlu ada perhatian dan dukungan dari pihak sekolah untuk (1) menekan biaya pendidikan (khususnya sekolah swasta); (2) menyediakan buku dan bahan ajar yang dapat dibawa pulang siswa atau orangtua/wali; dan (3) agar guru lebih kreatif dari sekedar membagikan LKPD kepada siswa, namun tetap menjaga kontak dan komunikasi dengan siswa dan orang tua, sehingga motivasi belajar anak tetap terjaga.

\section{PEMBAHASAN}

Temuan penelitian di atas menujukan bila hampir seluruh orang tua merasa kuatir atas dampak negatif pandemi Covid-19 terhadap pendidikan anak-anak mereka. Kekuatiran tersebut menyangkut pencapaian prestasi akademik siswa, pemerolehan ilmu pengatahuan, dan sejumlah kecakapan (kompetensi) yang sulit dicapai secara signifikan. "Tantangan saat ini adalah bagaimana agar pembelajaran jarak jauh bisa mencapai kompetensi dan tujuan pembelajaran yang tidak berbeda secara signifikan dengan pembelajaran tatap muka, bahkan boleh lebih baik" (Maman F. dalam Febrianti 2020). ${ }^{21}$ Krisis ini kemungkinan besar akan memeliki efek jangka panjang yang signifikan pada pendidikan termasuk kurikulum dan pembelajaran. Karena itu, hendaknya krisis ini dapat menjadi kesempatan untuk memikirkan kembali kurikulum, proses belajarmengajar-penilaian dan pengembangan kompetensi peserta didik dengan tujuan untuk memperkuat keterampilan belajar mereka dan mempertahankan motivasi mereka. ${ }^{22}$

22 UNESCO, “COVID-19 Crisis and Curriculum: Sustaining Quality Outcomes in the Context of Remote Learning," UNESDOC Digital Library, no. 4.2 (2020): 16, accessed September 7, 2020, https://unesdoc. unesco.org/ark:/48223/pf0000373273. 
Keterlibatan yang kurang memadai dari orang tua dan keluarga untuk mendukung aktivitas belajar jarak jauh anak di rumah, secara dominan disebabkan oleh keterbatasan waktu dan kecakapan orang tua untuk mendampingi anak-anak dalam belajar. Dua faktor yang adalah, ekonomi dan sosial ini tak jarang menjadi kendala dan tantangan serius penyelenggaraan pendidikan dalam konteks penelitian. Orang tua sibuk bekerja dalam berbagai profesi dan jenis pekerjaan untuk mendapatkan penghasilan guna menutup biaya pemenuhan kebutuhann keluarga, sehingga tidak memiliki waktu yang cukup untuk mendampingi anak-anak dalam belajar. Di sisi lain pendidikan orang tua juga turut berdampak terhadap frekuensi keterlibatan anak dalam akivitas akademik. Anak-anak dalam keluarga berpendidikan tinggi lebih sering terlibat dalam kegiatan akademik terstruktur seperti lembar kerja, sumber daya sekolah online, dan sumber daya pendidikan lainnya selama pandemi. ${ }^{23}$

Temuan ini sejalan dengan studi sebelumya bahwa "kurangnya kesadaran orang tua dan minat dalam kegiatan sekolah siswa adalah penyebab utama buruknya prestasi akademik mereka di sekolah menengah." 24 "Keterlibatan dan investasi orang tua memiliki efek yang signifikan pada konsep diri siswa dan prestasi akademik di sekolah dasar." 25 Keterlibatan orang tua dalam pendidikan anak secara konsisten ditemukan terkait secara positif dengan kinerja akademik anak. ${ }^{26}$

Beralih dari persepsi aktual ke tindakan orang tua dalam mendukung belajar dari rumah. Tidak banyak yang dilakukan orang tua untuk

23 Edith Greenlee and Alana Reid, "Parents Supporting Learning at Home during the COVID-19 Pandemic," Statistic Canada, last modified 2020, accessed September 9, 2020, https:/ / www150.statcan. gc.ca/n1/pub/45-28-0001/2020001/article/00040eng.htm.

${ }^{24}$ Junaid Aman et al., "Parental Involvement for Better Education: The Relationship between Parental Awareness, Emotional Support, and Children's Academic Achievement at Secondary Level," Masyarakat, Kebudayaan dan Politik 32, no. 4 (October 31, 2019): 334, https://e-journal.unair.ac.id/MKP/ article/view/14404.

25 Esther Sui-Chu Ho and Wai-Man Kwong, "Effects of Parental Involvement and Investment on Student Learning," in Parental Involvement on Children's Education, 2013, 131-148, mendukung aktivitas anak mereka di rumah. Kecuali bahwa orang tua pada akhirnya wajib menyediakan kebutuhan internet, memeriksa lembar kerja peserta didik dan semampunya membantu anak-anak memperjelas materi pelajaran yang diperoleh dari sekolah. Situasi ini semakin diperburuk oleh minimnya komunikasi antar guru dengan orang tua dan peserta didik yang berdampak pada menurunnya motivasi belajar anak. Meskipun situasi ini adalah masa krisis, tetapi untuk jangka panjang adalah sangat tidak baik bagi perkembangan pendidikan dan pencapaian prestasi akademik anak. Beberapa hasil penelitian telah memberi bukti bahwa keterlibatan orang tua dan keluarga dalam pembelajaran anak berdampak positif terhadap prestasi anak. ${ }^{27}$

Berdiskusi tentang tantangan yang dihadapi oleh orang tua siswa dalam kaitan belajar, temuan penelitian didominasi oleh 3 faktor, yakni meningkatnya pengeluaran keluarga (aspek ekonomi); stress orang tua karena meningkatnya tekanan mengelola pembatasan (karantina) dan pekerjaan (gangguan psikologi), serta hubungan dan komunikasi (aspek sosial) orang tua dengan anak, juga antara orang tua dan guru.

Beberapa hasil penelitian sebelumnya menunjukkan indikasi yang sama. Hasil penelitian Azzahra (2020) menunjukkan bahwa gangguan terhadap sistem pendidikan tradisional saat ini telah merugikan siswa-siswa yang berasal dari keluarga prasejahtera dan yang berada di daerah pedesaan. Siswa yang bahkan dalam kondisi normal, telah menghadapi hambatan untuk mengakses pendidikan, dan

http:/ /link.springer.com/10.1007/978-981-4021-999_5.

${ }^{26}$ David R. Topor et al., "Parent Involvement and Student Academic Performance: A Multiple Mediational Analysis," Journal of Prevention $\mathcal{E}$ Intervention in the Community 38, no. 3 (June 30, 2010): 183-197,

http:/ / www.tandfonline.com/doi/abs/10.1080/108 52352.2010.486297.

${ }^{27}$ Robin Averill, Abby Metson, and Susan Bailey, "Enhancing Parental Involvement in Student Learning," Curriculum Matters 12 (December 1, 2016): 109-131,

http://www.nzcer.org.nz/nzcerpress/curriculummatters/articles/enhancing-parental-involvementstudent-learning. 
sekarang mereka menghadapi hambatan tambahan yang muncul akibat ketidaksetaraan untuk mengakses infrastruktur teknologi. ${ }^{28}$ Meningkatnya biaya yang ditanggung orang tua dalam kaitan belajar dari rumah juga didukung oleh hasil penelitian SMRC: "Di antara responden dengan anggota keluarga yang melakukan pembelajaran jarak jauh, 67 persen menyatakan sangat atau cukup mahal." 2930.

Peningkatan gangguan psikologi orang tua terjadi karena keterbatasan kemampuan dalam mengelola pembatasan-pembatasan (karantina) yang diberlakukan (bnd. Spinelli et al., 2020). ${ }^{31}$ Orang tua kesulitan menyeimbangkan waktu antara pekerjaan sehari-hari dan pendampingan aktivitas belajar anak di rumah, juga mengeluh atas rumitnya melaksanakan peran sebagai guru di rumah. Beberapa orang tua mengaku bila ada situasi di mana anak-anak lebih tunduk dan hormat kepada guru di sekolah dari pada orang tua di rumah.

Menurut penulis masalah-masalah terkait lebih disebabkan oleh kesiapan orang tua menjadi guru di rumah. Orangtua dituntut memfasilitasi kebutuhan belajar daring anak di rumah, konsekuensinya adalah penyediaan menyediakan gadget/notebook atau berbagi gadget dengan anak; pengeluaran tambahan pengeluaran untuk beli paket data. Orangtua

${ }^{28}$ Nadia Fairuza Azzahra, “Mengkaji Hambatan Pembelajaran Jarak Jauh Di Indonesia Di Masa Pandemi Covid-19," Center for Indonesians Policy Studies 19, no. 2 (2020): 1-9, accessed September 8, 2020, https://www.cipsindonesia.org/post/mengkaji-hambatanpembelajaran-jarakjauhdi-indonesia-di-masa-covid19.

${ }^{29}$ SMRC, "Mayoritas Warga Menganggap Berat Biaya Pendidikan Online," SaifulMuljani Research $\mathcal{E}$ Consulting, last modified 2020, accessed September 8, 2020, https://saifulmujani.com/mayoritas-wargamenganggap-berat-biaya-pendidikan-online/.

30 Ghaliya Ghina, "Majority of Indonesians Find Distance Learning Costly: Study," The Jakarta Post (Jakarta, 2020), accessed September 8, 2020, https://www.thejakartapost.com/news/2020/08/19 / majority-of-indonesians-find-distance-learningcostly-study.html.

31 Maria Spinelli et al., "Parents' Stress and Children's Psychological Problems in Families Facing the COVID-19 Outbreak in Italy," Frontiers in Psychology 11 (July 3, 2020), https://www.frontiersin.org/article/10.3389/fpsyg. 2020.01713/full. harus mampu dalam mengelola dan membagi waktu antara mengerjakan tugas sehari-hari dan mendampingi anak dalam belajar di rumah, dan pada akhirnya orangtua berperan sebagai guru bagi anaknya. 3233

Temuan yang mengejutkan dalam penelitian ini adalah $48,4 \%$ orang tua mengaku bahwa motivasi belajar anak-anak mereka mengalami penurunan. Disebabkan oleh banyaknya tugas yang harus dikerjakan dalam waktu sempit, metode belajar yang kurang menyenangkan, dan terbatasnya interaksi dengan teman. Ketidakmampuan untuk belajar secara efektif dalam format online, dan lingkungan rumah yang mengganggu atau kurangnya akses ke ruang belajar yang sesuai.

Temuan ini sejalan dengan laporan Save the Children dalam CNN Indonesia (2020) bahwa "Sebanyak 42 persen responden orang tua mengaku motivasi belajar anak kian menurun dari waktu ke waktu selama masa pandemi." 34 Kelas virtual seringkali membingungkan dan berisi informasi yang berlebihan untuk dilacak. Tenggat waktu tidak pasti, tugas menyesatkan, dan ujian sangat sulit bagi siswa untuk dipelajari. ${ }^{35}$ Kondisi lingkungan belajar dan keluarga yang tidak kondusif, juga berkontribusi

32 Nono Hery Yoenanto, Kesiapan Orangtua Menjadi Guru Di Rumah (Surabaya, 2020), https://psikologi.unair.ac.id/wpcontent/uploads/2020/05/13-Kesiapan-OrangtuaMenjadi-'Guru'-di-Rumah.pdf.

33 Tsaniya Zahra Yuthika Wardhani and Hetty Krisnani, "OPTIMALISASI PERAN PENGAWASAN ORANG TUA DALAM PELAKSANAAN SEKOLAH ONLINE DI MASA PANDEMI COVID-19," Prosiding Penelitian dan Pengabdian kepada Masyarakat 7, no. 1 (July 14, 2020): 48, http://jurnal.unpad.ac.id/ prosiding/article/view/28256.

34 CNN Indonesia, "7 Dampak Pandemi Yang Berisiko Dihadapi Anak-Anak," CNN Indonesia (Jakarta, 2020), https://www.cnnindonesia.com/ gaya-hidup/20200722142651-284-527653/7-dampakpandemi-yang-berisiko-dihadapi-anak-anak.

35 Anna Nell, Miles Hood, and Haylee Graff, Student Motivation During COVID 19 Pandemic, AES Academic Advising Center (A\&S Academic Advising Center, 2020), accessed September 12, 2020, https://www.colorado.edu/artssciencesadvising/2020/04/21/student-motivation-duringcovid-19-pandemic. 
terhadap menurunya motivasi belajar anakanak $^{36}$, lihat juga Daugherty (2020). ${ }^{37}$

Hidup berdampingan dengan Covid-19 merupakan realita kehidupan baru saat ini. Kita tidak dapat memrediksi kapan kiris ini akan berakhir. Wabah ini setiap saat mengancam kesehatan dan keselamatan; segala sesuatu dijalankan dengan protokol kesehatan, dengan pembatasan-pembatasan tentunya. Namun, perlu disadari bahwa integrasi teknologi ke dalam proses pembelajaran merupakan hal yang tidak bisa dihindari. Kelas sudah tidak bisa lagi dibatasi dengan dinding di mana pembelajaran berlangsung secara konvensional. Di era ini, anak-anak telah memiliki preferensi belajar sendiri-sendiri, mereka lahir dimana teknologi telah berkembang pesat. Institusi pendidikan tengah berada di era perkembangan teknologi yang cepat dan masif (revolusi industri 4.0). Setuju tidak setuju lembaga pendidikan harus beradaptasi dan merancang ulang sistem manajemen "pembelajaran yang merujuk pada pembelajaan berbasis TIK, internet of things, big data dan komputer." 38

Fisk (2020) menyatakan bahwa ada sembilan tren terkait dengan pendidikan 4.0, di antaranya adalah "belajar pada waktu dan tempat yang berbeda, dan e-learning memfasilitasi kesempatan untuk pembelajaran jarak jauh dan mandiri." 39 Ini menjukan bahwa wabah covid-19 menjadi alat pemicu untuk segera beradaptasi dengan perkembangan teknologi melalui pengintegrasian teknologi ke dalam proses pembelajaran. Pemikiran ini juga sejalan dengan Dunwil (2016), bahwa akan banyak perubahan di masa depan. Dia memperkirakan bagaimana kecederungan kelas akan terlihat dalam 5-7 tahun ke depan, yakni (a)

36 Adhetya Cahyani, Iin Diah Listiana, and Sari Puteri Deta Larasati, "Motivasi Belajar Siswa SMA Pada Pembelajaran Daring Di Masa Pandemi Covid19," IQ (Ilmu Al-qur'an): Jurnal Pendidikan Islam 3, no. 01 (July 31, 2020): 123-140, http://journal.ptiq.ac.id/index.php/iq/article/view $/ 57$.

${ }^{37}$ Owen Daugherty, Students Face Obstacles, Lack of Motivation in Transition to Remote Learning Amid Pandemic, NASFAA (Washington, D.C., D.C.: NASFAA, 2020), accessed September 12, 2020, https://www.nasfaa.org/newsitem/22637/Students_Face_Obstacles_Lack_of_Moti vation_in_Transition_to_Remote_Learning_Amid_Pa ndemic_Report_Finds. perubahan besar dalam tata ruang kelas, (b) virtual dan augmented reality akan mengubah lanskap pendidikan, (c) Tugas yang fleksibel yang mengakomodasi banyak preferensi belajar, dan (d) MOOC dan opsi pembelajaran online lainnya akan berdampak pada pendidikan menengah. ${ }^{40}$

Meningkatnya biaya yang harus ditanggung orang tua dalam mendukung keberlanjutan pendidikan anak-anak, dapat saja dengan mudah dijawab oleh pemerintah melalui penyediaan paket internet (kebijakan ini tengah berlangsung). Namun dalam jangka menengah dan panjang tersedianya infrastruktur teknologi yang dijangkau oleh segenap komponen masyarakat merupakan pekerjaan mendesak bagi pemerintah. Pemerintah daerah sudah harus mengambil inisiatif untuk bekerja sama dengan perusahaan pengembang infrastruktur teknologi komunikasi tanpa harus menunggu tersediannya anggaran dari pemerintah pusat.

\section{Minimnya} kecakapan guru mengintegrasikan teknologi dalam proses pembelajaran adalah tantangan tersendiri dan memerlukan perhatian serius dari pemerintah. Rencana Program Organisasi Penggerak (POP) yang digagas oleh Kementerian Pendidikan dan Kebudaaann RI adalah harapan baru bagi peningkatan kualitas pendidikan. POP merupakan program pemberdayaan masyarakat secara masif melalui dukungan pemerintah untuk peningkatan kualitas guru dan kepala sekolah berdasarkan model-model pelatihan yang sudah terbukti efektif dalam meningkatkan kualitas proses pembelajaran dan hasil belajar siswa (Kemendikbud, 2020). Mengingat persoalan pendidikan juga terkait dengan keterlibatan orang tua dalam pendidikan anak,

38 Delipiter Lase, "Education and Industrial Revolution 4.0," Handayani Journal PGSD FIP Unimed 10, no. 1 (2019): 48-62, https://jurnal.unimed.ac.id/ 2012/index.php/handayani/issue/view/1649.

39 Peter Fisk, "Education 4.0 ... the Future of Learning Will Be Dramatically Different, in School and throughout Life," last modified 2017, accessed May 11, 2019, http://www.thegeniusworks.com/2017/01/ future-education-young-everyone-taught-together/.

40 E. Dunwill, " 4 Changes That Will Shape the Classroom of the Future: Making Education Fully Technological" (2016), https://elearningindustry. com/4-changes-will-shape-classroom-of-the-futuremaking-education-fully-technological. 
maka program ini perlu memberi tempat terhadap aktivitas kampanye guna membangunn keasadaran orang tua untuk meningkatkan keterlibatannya pada proses pendidikan anak-anak.

Di atas semua itu, yang utama adalah perubahan paradigma orang tua untuk menyiapkan diri menjadi guru bagi anakanaknya di rumah. Karena itu, beberapa petunjuk di bawah ini diharapkan dapat membantu orang tua mengajar di rumah.

- Mengatur waktu belajar anak, belajar dan menyelesaikan tugas analitik (seperti, matematika) paling baik dilakukan pada pagi hari. 41

- Suasana hati dan perasaan anak-anak memengaruhi produktivitas belajar mereka. Karena itu, orangtua perlu memeriksa suasana hati anak melalui berbagai pertanyaan. Ini dapat dilakukan setiap hari, bahkan sepanjang hari.

- Sebelum orang tua campur tangan, doronglah anak-anak untuk menyelesaikan masalah mereka pada tingkat kemampuan tertinggi dan berikanlah pengakuan atau pujian untuk itu.

- Melibatkan anak-anak dalam kegiatan lain seperti diskusi, menulis, menggambar, menari, mendengarkan musik sangat baik untuk meningkatkan kreativitas, empati, dan keterampilan bahasa mereka.

- Orang tua perlu memberikan waktu bagi anak-anak untuk bermain atau berolahraga.

- Orang tua tidak perlu membatasi tempat belajar anak-anak di rumah, sejauh mungkin, mereka dapat belajar di mana saja di rumah.

\section{KONKLUSI}

Bertolak dari temuan penelitian di atas, terdapat setidak-tidaknya tiga isu utama terkait kepentingan orang tua terhadap pembelajaran jarak jauh, khususnya pada konteks penelitian dan secara umum di daerah pedalaman (rural) Indonesia. Yakni, menyangkut masalah paradigma konservatif orang tua tentang pendidikan adalah tanggung jawab institusi pendidikan; penurunan motivasi belajar anak dalam bingkai study from home; serta

${ }^{41}$ Wendy Sjosten-bell, “Influence of Time-of-Day on Student Performance on Mathematical infrastruktur teknologi yang terdistribusi secara tidak merata di seluruh wilayah Indonesia.

Kekeliruan mayoritas orang tua dalam memahami pendidikan adalah tanggung jawab institusi pendidikan telah menyebabkan keterlibatan mereka dalam pendidikan anak dan kesiapan menjadi guru bagi anak di rumah berada pada level terendah. Sementara, hasilhasil penelitian telah memberi bukti bahwa keterlibatan orang tua pada proses pendidikan anak berkontribusi positif pada pencapaian akademis mereka.

Sepakat bahwa penurunan motivasi belajar anak-anak pada masa krisis ini bukanlah merupakan persoalan yang lahir secara tunggal, tetapi merupakan kontribusi dari lingkungan baik ekternal maupun internal anak itu sendiri. Di sinilah peran maksimum orang tua diperlukan, dan bahkan semakin baik ketika anggota keluarga lainya terlibat dalam mendukung aktivitas study from home anak-anak. Membangun komunikasi yang terus-menerus antara orang tua dengan guru, orang tua dengan anak, guru dengan siswa dan siswa dengan kelompoknya akan sangat membantu motivasi intrinsik anak tetap bertumbuh dan terjaga. Bahkan efek stress yang dialami oleh orang tua dan siswa pun, dapat ditangani melalui komunikasi yang intens di antara mereka.

Terkait dengan ketersediaan infrastruktur telekomuniaksi untuk mendukung proses penyelenggaraan pendidikan yang berbasis ICT. Ini bukanlah pekerjaan kecil, murah dan cepat. Ini membutuhkan itikad baik dari semua pihak utamanya pemerintah yang memiliki otoritas dan anggaran yang besar. Selain kesehatan, pemerintah daerah harus berani memberi priortas penanganan pada aspek ini. Demikian halnya dengan institusi pendidikan (sekolah), dana atau biaya operasional sekolah yang berasal dari keuangan pemerintah pusat akan semakin baik jika sebagiannya diperuntukan pada peningkatan aksesbilitas peserta didik terhadap layanan pendidikan berbasis teknologi.

Lebih lanjut, tiap tahun desa-desa di Indonesia menerima kuncuran dana dari pemerintah pusat dari ratusan juta ke milyaran rupiah dalam rangka membangun Indonesia dari pingguran desa (Setkab RI). Melalui kerjasama

Algorithms," Dominican University of California (Dominican University of California, 2005). 
antar desa, dana ini dapat dimanfaatkan untuk percepatan pemerataan aksesbilitas jaringan telekomonikasi di pelosok daerah.

\section{UCAPAN TERIMAKASIH}

Peneitian ini tentunya akan sulit diselesaikan tanpa dukungan dari berbagai pihak. Karena itu, pada kesempatan ini penulis menyampaikan terimakaksih yang sedalamdalamnya kepada Dinas Pendidikan Kota Gunungsitoli, terutama kepada bapak Angalita Zebua. Juga, kepada para kepala sekolah dan wali kelas, GAMKI Kota Gunungsitoli dan mahasiswa STT Banua Niha Keriso Portestan Sundermann Nias. Mereka telah mendukung penelitian ini dalam bentuk penyediaan dan pengumpulan data.

\section{REFERENSI}

Adnan, Muhammad, and Kainat Anwar. "Online Learning amid the COVID-19 Pandemic: Students' Perspectives." Journal of Pedagogical Sociology and Psychology 2, no. 1 (2020): 45-51. https://www.j-psp.com/article/onlinelearning-amid-the-covid-19-pandemicstudents-perspectives-8355.

Aman, Junaid, Muhammad Babar Akram, Siti Mas'udah, Muhammad Saud, and Yasir Nawaz Manj. "Parental Involvement for Better Education: The Relationship between Parental Awareness, Emotional Support, and Children's Academic Achievement at Secondary Level." Masyarakat, Kebudayaan dan Politik 32, no. 4 (October 31, 2019): 334. https://ejournal.unair.ac.id/MKP/article/view/14404

Arifin, Haris Nursyah. "Respon Siswa Terhadap Pembelajaran Dalam Jaringan Masa Pandemi COVID-19 Di Madrasah Aliyah Al-Amin Tabanan." WIDYA BALINA: Jurnal Ilmu Pendidikan dan Ekonomi 5, no. 9 (2020): 1-12. https://journal.staidenpasar.ac.id/index.php /wb/article/view/47.

Averill, Robin, Abby Metson, and Susan Bailey. "Enhancing Parental Involvement in Student Learning." Curriculum Matters 12 (December 1, 2016): 109-131.

http://www.nzcer.org.nz/nzcerpress/curric ulum-matters/articles/enhancing-parentalinvolvement-student-learning.

Azzahra, Nadia Fairuza. "Mengkaji Hambatan
Pembelajaran Jarak Jauh Di Indonesia Di

Masa Pandemi Covid-19." Center for

Indonesians Policy Studies 19, no. 2 (2020): 1-9.

Accessed September 8, 2020.

https://www.cips-

indonesia.org/post/mengkaji-hambatanpembelajaran-jarak-jauhdi-indonesia-dimasa-covid-19.

Bernard, H Russell, and Bernard H. Russell. Reserach Methods in Anthropology - Qualitative and Quantitative Approaches. AltaMira Press.

Walnut Creek: AltaMira Press, 2006.

Braun, Virginia, and Victoria Clarke. "Using Thematic Analysis in Psychology." Qualitative Research in Psychology 3, no. 2 (January 2006): 77-101.

http://www.tandfonline.com/doi/abs/10.1 191/1478088706qp063oa.

Cahyani, Adhetya, Iin Diah Listiana, and Sari Puteri Deta Larasati. "Motivasi Belajar Siswa SMA Pada Pembelajaran Daring Di Masa Pandemi Covid-19." IQ (Ilmu Al-qur'an): Jurnal Pendidikan Islam 3, no. 01 (July 31, 2020): 123-140.

http://journal.ptiq.ac.id/index.php/iq/articl e/view/57.

CNN Indonesia. "7 Dampak Pandemi Yang Berisiko Dihadapi Anak-Anak." CNN Indonesia. Jakarta, 2020.

https://www.cnnindonesia.com/gayahidup/20200722142651-284-527653/7dampak-pandemi-yang-berisiko-dihadapianak-anak.

Daugherty, Owen. Students Face Obstacles, Lack of Motivation in Transition to Remote Learning Amid Pandemic. NASFAA. Washington, D.C., D.C.: NASFAA, 2020. Accessed September 12, 2020. https:/ / www.nasfaa.org/newsitem/22637/Students_Face_Obstacles_Lack_ of_Motivation_in_Transition_to_Remote_Lea rning_Amid_Pandemic_Report_Finds.

Dewi, Wahyu Aji Fatma. "Dampak COVID-19 Terhadap Implementasi Pembelajaran Daring Di Sekolah Dasar." EDUKATIF : JURNAL ILMU PENDIDIKAN 2, no. 1 (2020): 55-61. https://edukatif.org/index.php/edukatif/ar ticle/view/89.

Dunwill, E. "4 Changes That Will Shape the Classroom of the Future: Making Education Fully Technological" (2016). https://elearningindustry.com/4-changeswill-shape-classroom-of-the-future-makingeducation-fully-technological.

Faqir, Anisyah Al. "Kemendikbud Catat 646.200 Sekolah Tutup Akibat Virus Corona," 2020. https://www.merdeka.com/uang/kemendi 
kbud-catat-646200-sekolah-tutup-akibatvirus-corona.html.

Febrianti, Riska. "Implementasi Kurikulum Dan Pembelajaran Di Masa Pandemi Covid-19."

Universitas Negeri Malang. Last modified 2020. Accessed July 15, 2020.

https://um.ac.id/berita/implementasikurikulum-dan-pembelajaran-di-masapandemi-covid-19/.

Fisk, Peter. "Education 4.0 ... the Future of Learning Will Be Dramatically Different, in School and throughout Life." Last modified 2017. Accessed May 11, 2019. http://www.thegeniusworks.com/2017/01/ future-education-young-everyone-taughttogether/.

Ghaliya Ghina. "Majority of Indonesians Find Distance Learning Costly: Study." The Jakarta Post. Jakarta, 2020. Accessed September 8, 2020.

https://www.thejakartapost.com/news/202 0/08/19/majority-of-indonesians-finddistance-learning-costly-study.html.

Greenlee, Edith, and Alana Reid. "Parents Supporting Learning at Home during the COVID-19 Pandemic." Statistic Canada. Last modified 2020. Accessed September 9, 2020. https://www150.statcan.gc.ca/n1/pub/4528-0001/2020001/article/00040-eng.htm.

Heriyanto, Heriyanto. “Thematic Analysis Sebagai Metode Menganalisa Data Untuk Penelitian Kualitatif." Anuva 2, no. 3 (November 22, 2018): 317.

https://ejournal2.undip.ac.id/index.php/an uva/article/view/3679.

Herliandry, Luh Devi, Nurhasanah, Maria Enjelina Suban, and Heru Kuswanto. "Pembelajaran Pada Masa Pandemi Covid-19" 22, no. 1 (2020): 65-70. http://journal.unj.ac.id/unj/index.php/jtp.

Ho, Esther Sui-Chu, and Wai-Man Kwong. "Effects of Parental Involvement and Investment on Student Learning." In Parental Involvement on Children's Education, 131-148, 2013. http://link.springer.com/10.1007/978-9814021-99-9_5.

Jandrić, Petar. "Postdigital Research in the Time of Covid-19." Postdigital Science and Education 2, no. 2 (April 21, 2020): 233-238. Accessed May $15,2020$.

http://link.springer.com/10.1007/s42438020-00113-8.

Krishnapatria, Kriswanda. "From 'Lockdown' to Letdown: Students' Perception of E-Learning amid the COVID-19 Outbreak." ELT in Focus 3, no. 1 (2020): 1-8.
https://journal.unsika.ac.id/index.php/ELT INFOCUS/article/view/3694.

Lase, Delipiter. "Education and Industrial Revolution 4.0." Handayani Journal PGSD FIP Unimed 10, no. 1 (2019): 48-62. https://jurnal.unimed.ac.id/2012/index.php /handayani/issue/view/1649.

Lincoln, Yvonna S, and Egon G Guba. Naturalist Inquiry. Beverly Hills, CA: Sage, 1985.

Marshall, Catherine, and Gretchen B. Rossman. Designing Qualitative Research. 6th ed. Thousand Oaks, CA: SAGE Publications, Inc., 2015.

Megawanti, Priarti, Erna Megawati, and Siti Nurkhafifah. "Persepsi Peserta Didik Terhadap PJJ Pada Masa Pandemi Covid 19." Faktor Jurnal Ilmiah Kependidikan 7, no. 2 (2020): 75-82.

Moleong, Lexy J. Metodologi Penelitian Kualitatif. Bandung: PT Remaja Rosdakarya, 2012.

Nell, Anna, Miles Hood, and Haylee Graff. Student Motivation During COVID 19 Pandemic. AES Academic Advising Center. A\&S Academic Advising Center, 2020. Accessed September 12, 2020.

https://www.colorado.edu/artssciencesadvising/2020/04/21/student-motivationduring-covid-19-pandemic.

Pei, Leisi, and Hongbin Wu. "Does Online Learning Work Better than Offline Learning in Undergraduate Medical Education? A Systematic Review and Meta-Analysis." Medical Education Online 24, no. 1 (January 1, 2019): 1666538.

https://www.tandfonline.com/doi/full/10.1 080/10872981.2019.1666538.

Puspita, Ratna. "Kemendikbud: 68 Juta Siswa Terdampak Pandemi Covid-19." REPUBLIKA.Co.Id. Jakarta, August 4, 2020. https://republika.co.id/berita/qejb7r428/ke mendikbud-68-juta-siswa-terdampakpandemi-covid19.

Putri, Ratna Setyowati, Agus Purwanto, Rudy Pramono, Masduki Asbari, Laksmi Mayesti Wijayanti, and Choi Chi Hyun. "Impact of the COVID-19 Pandemic on Online Home Learning: An Explorative Study of Primary Schools in Indonesia." International Journal of Advanced Science and Technology 29, no. 05 (2020): 4809-4818.

http://sersc.org/journals/index.php/IJAST /article/view/13867.

Sjosten-bell, Wendy. "Influence of Time-of-Day on Student Performance on Mathematical Algorithms." Dominican University of California. Dominican University of 
California, 2005.

Skulmowski, Alexander, and Günter Daniel Rey.

"COVID-19 as an Accelerator for

Digitalization at a German University:

Establishing Hybrid Campuses in Times of

Crisis." Human Behavior and Emerging

Technologies 2, no. 3 (2020): 212-216.

SMRC. "Mayoritas Warga Menganggap Berat

Biaya Pendidikan Online." SaifulMuljani

Research E Consulting. Last modified 2020.

Accessed September 8, 2020.

https://saifulmujani.com/mayoritas-warga-

menganggap-berat-biaya-pendidikan-

online/.

Spinelli, Maria, Francesca Lionetti, Massimiliano Pastore, and Mirco Fasolo. "Parents' Stress and Children's Psychological Problems in Families Facing the COVID-19 Outbreak in Italy." Frontiers in Psychology 11 (July 3, 2020). https://www.frontiersin.org/article/10.3389 /fpsyg.2020.01713/full.

Topor, David R., Susan P. Keane, Terri L. Shelton, and Susan D. Calkins. "Parent Involvement and Student Academic Performance: A Multiple Mediational Analysis." Journal of Prevention \& Intervention in the Community 38, no. 3 (June 30, 2010): 183-197.

http://www.tandfonline.com/doi/abs/10.1 080/10852352.2010.486297.

UNESCO. "COVID-19 Crisis and Curriculum:

Sustaining Quality Outcomes in the Context of Remote Learning." UNESDOC Digital Library, no. 4.2 (2020): 1-6. Accessed

September 7, 2020.

https://unesdoc.unesco.org/ark:/48223/pf0 000373273.

- - - . "School Closures Caused by Coronavirus (Covid-19)." Unesco, 2020. Accessed June 2, 2020.

https://en.unesco.org/covid19/educationres ponse.

Viva. "Terdampak Corona, 34,5 Persen Pelajar Indonesia Tak Terakses Pendidikan Online." Suara Merdeka. Jakarta, April 4, 2020. https://www.suaramerdeka.com/news/nasi onal/224640-terdampak-corona-345-persenpelajar-indonesia-tak-terakses-pendidikanonline.

Wardhani, Tsaniya Zahra Yuthika, and Hetty

Krisnani. “OPTIMALISASI PERAN

PENGAWASAN ORANG TUA DALAM

PELAKSANAAN SEKOLAH ONLINE DI

MASA PANDEMI COVID-19." Prosiding

Penelitian dan Pengabdian kepada Masyarakat 7, no. 1 (July 14, 2020): 48.

http://jurnal.unpad.ac.id/prosiding/article/ view/28256.

Yoenanto, Nono Hery. Kesiapan Orangtua Menjadi Guru Di Rumah. Surabaya, 2020. https://psikologi.unair.ac.id/wpcontent/uploads/2020/05/13-KesiapanOrangtua-Menjadi-'Guru'-di-Rumah.pdf.

Zaharah, Zaharah, and Galia Ildusovna Kirilova. "Impact of Corona Virus Outbreak Towards Teaching and Learning Activities in Indonesia." SALAM: Jurnal Sosial dan Budaya Syar-i 7, no. 3 (March 26, 2020). http://journal.uinjkt.ac.id/index.php/salam /article/view/15104. 